\title{
An empirical study on socialization counseling needs of adolescents in Indian schools
}

\section{ABSTRACT:}

\author{
Sri Bhagavad Gita Narahari ${ }^{1}$, K. N. Tripathi ${ }^{2}$
}

Adolescence is a turbulent time and vulnerable phase of curious experiences. Socialization is a process wherein, there is also a need to develop social relations which is intensified during adolescence and continues to be essential all through life. Hence, the immense human potential at this stage may be well optimized or undermined. Counseling is an interactive process which may enhance social behavior, discrimination, well-being and adaptation. Present study is an attempt to understand the socialization counseling needs of adolescents studying in different schools of India. A random sample of adolescents $(\mathrm{N}=300)$ studying in three different schools, government, private and missionary are chosen with respect to class, gender and socio-economic status (SES) for study on need for socialization counseling. The results indicated that adolescent students from government school displayed higher need for socialization counseling when compared to students belonging to private and missionary schools. The results for gender differences indicated that there was no significant difference for the need of socialization counseling, whereas the interaction of gender with class was significant. Further, the effects of gender with class and school were not significant. Moreover, results for adolescents belonging to middle and higher SES group showed greater need for socialization counseling in comparison to low SES group. Hence, this study emphasizes a possibility to strengthen the adolescent's psychological orientation through socialization counseling in academic environment.

Keywords: Socialization, Adolescence, Counseling, Indian schools, Socio-economic status, Gender

\section{INTRODUCTION:}

The earliest usage of the word 'adolescence' seems to appear around $15^{\text {th }}$ century. The term was a derivative of the latin word adolescere, which means to grow up or to grow into maturity (Muss, 1990). Adolescence is the period of development marked approximately at the beginning by the onset of puberty and at the end by the attainment of physiological and psychological maturity (Reber, 1995).

\footnotetext{
${ }^{1}$ Department of Management, School of Management, ITM University, Gwalior, Madhya Pradesh, India ${ }^{2}$ Department of Psychology, Barkatullah Vishwavidhyalaya, Hoshangabad Road, Habibganj, Bhopal, Madhya Pradesh, India.

(c) 2015 I B Narahari, K Tripathi; licensee IJIP. This is an Open Access Research distributed under the terms of the Creative Commons Attribution License (http://creativecommons.org/licenses/by/2.0), which permits unrestricted use, distribution, and reproduction in any Medium, provided the original work is properly cited.
} 
The adolescents falling between the age groups thirteen and nineteen may be called as teenagers and popularly referred as 'teens'. Many adolescents go through bouts of unrealism. Many wellknown adolescent difficulties are not intrinsic to the teenage years but are related to the mismatch between adolescents' developmental needs and the kinds of experiences most junior and high school provide (Linda Darling-Hammond, 1997). Some problems are more likely to appear at certain developmental level than at another. It was found that depression; truancy and drug abuse were more common among older adolescents, while fighting, arguing and being too loud were found among younger adolescents (Edelbrock, 1989). According to Erikson (1963a, b) it was almost essential for adolescents to go through identity crisis. Adolescents use hypothetical-deductive reasoning, which means that they develop hypotheses or best guesses, and systematically deduce, or conclude, which is the best path to follow in solving the problem (Inhelder and Piaget, 1958). Conventional morality is the level II and stage III of Kohlberg's theory (1969) which focuses on maintaining good interpersonal relationships by the teenager. It reflects that children who are entering into teenage see morality more than simple deeds and believe that people should live up to the expectations of the family and community and should behave according to expected agreed norms. To sum it up research supports that positive teens become healthy adults and adolescents with a brighter outlook on life may have better life and health in their adult years (Hoyt, 2011).

\section{Counseling needs}

Counseling is an interactive process characterized by a unique relationship between the counselor (one who counsels) and the counselee (one who is counseled), that leads to a change in one or more areas -behavior, beliefs, values and level of emotional distress (Elizabeth \& Patterson, 2005). Counseling psychology is an emerging field and mostly has been a silent contributor in providing community help. Counseling is a confidential relationship (Rosemary, 2002), and this relationship demands counselling for problem solving at the onset of adolescence. The need of adolescents in this hour is special focus and particular attention in the form of counseling in the area of socialization (Lee and Richard, 2003).

Research suggests that counseling helps to ameliorate the effects of discrimination too (Dunbar, 2001). Many qualitative studies have identified discrimination as a theme that clearly emerges in parents' narratives as well (Tatum, 1987; Urciuoli, 1996; Ward, 1991). The socialization of male and female child is generally discriminated right from a very early age which brings variation in the kind of social needs they experience. We have to bear the specific consequences of a traditional male socialization, which is more or less common amongst all societies across the world. Counseling needs of girl may be different than counseling needs of boys. Learning plays a vital role in shaping gender roles. It requires greater home involvement, with emphasis on enhanced parent responsibility for their children's behavior and learning. Incidents of bias towards gender still occur in classrooms (Boysen \& Vogel, 2008). Hence, adolescents should be 


\section{An empirical study on socialization counseling needs of adolescents in Indian schools}

sensitized towards gender-based attitudes through socialization counseling, which can contribute on a macro level as adults.

Socio-economic status (SES) is one more important measure of adolescent's environment and it is determined by factors mainly such as family income and the parents' levels of education and occupation. Many adolescents bring a wide range of problems stemming from restricted opportunities associated with poverty and low income, difficult and diverse family circumstances, lack of appropriate language skills, high rates of mobility, violent neighborhoods, problems relating to basic food, clothing and shelter, substance abuse, inadequate health care and lack of enrichment opportunities (Garbarino, 1995; Zill et al, 1995). Hence, adolescents belonging to families of any SES status, may greatly benefit from counseling making them optimally adaptive.

Educators and parents have long realized the fact that adolescents cannot be made to do things they are not interested in. Further, socialization is one aspect where Indian adolescents are less comfortable sharing their socialization experiences with parents and teachers. Hence, the present study is researched to understand their needs and address them through counseling intervention to deal with socialization of either gender in different types of schools and also at varied socioeconomic status to have better motivated lives. To study these parameters the following objectives were formulated.

\section{OBJECTIVES}

1. To understand the need for socialization counseling amongst adolescent students of different class and gender.

2. To study if socialization counselling needs differ as per the type of school.

3. To analyze the socialization counseling need with different socio-economic status of students.

\section{HYPOTHESIS}

In the light of research questions the following hypothesis were formulated.

H1. Need for counseling will vary significantly across different types of schools.

H2. Counseling need for socialization of male students will be significantly different from their counterpart female students.

H3. The students coming from different SES background will differ in their need for counseling.

\section{METHODOLOGY}

The whole study is designed and conducted in two phases. The first part is a pilot study in which the measures are finalized and developed. The second part involves the main study in which data are obtained on the measures and relationships among the variables are empirically examined.

The proposed research adopts an exploratory approach since not much systematic work has been done in this area. A total of $300(\mathrm{~N}=300)$ adolescent male and female students are selected from three types of schools, missionary, government and private schools located in India to participate in the present study. Schematic representation of the sample used for the study is given in 
Table.1. These students are studying in IX $(\mathrm{N}=150)$ and XI $(\mathrm{N}=150)$ class. The participants are drawn according to 2 (class levels) x 2 (male and female) x 3 (types of school) factorial design.

Table.1. Schematic representation of the sample

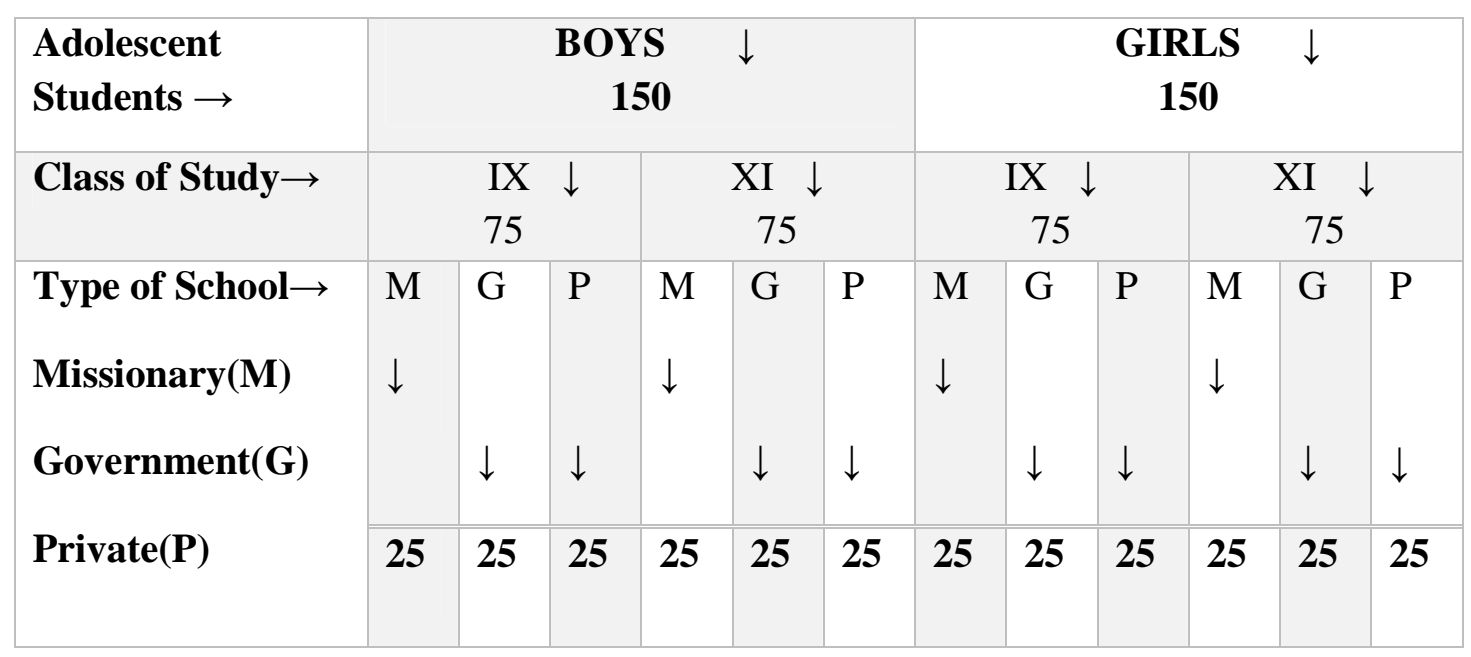

\section{MEASURES}

The following measures are used in the course of study.

The socialization counseling need is identified and researched. Counseling need questionnaire is timed for $30 \mathrm{~min}$. The counseling needs inventory has a five point rating scale. Participants responded to these questions on 30 items on a five point scale ranging from 'Not True' (1) to 'Highly True' (5).

\section{Measure of socio-economic status (SES)}

A SES scale (urban) presented by Dubey and Nigam (2005) is used in this study. The scale is designed to know the social position, economic and educational factors determining the SES of participants of all groups. This scale has a total of 30 questions where each item is followed by four alternatives. For every item, 4 marks are allotted for the first choice and 3 marks to the second choice and 2 marks to the third choice and 1 mark to the fourth choice. The sum of marks obtained on all the 30 questions help in interpreting the class of SES. The reliability of the test is calculated by Test-Retest method and the coefficient of correlation is found to be 0.81 scores. The range of scores less than or equal to 39 are categorized lower class and those scoring 40 or above are categorized as middle and upper class SES.

\section{RESULTS}

Means and standard deviations of the scores and summary of analysis of variance (ANOVA) for socialization counseling need for developing of social relations of students are given in Table. 2 and Table. 3 respectively. 
Table. 2. Means and Standard deviations of the scores indicating need for developing social relations

\begin{tabular}{|c|c|c|c|c|c|}
\hline Gender & Class & School & Mean & $\mathrm{SD}$ & $\mathrm{N}$ \\
\hline \multirow[t]{12}{*}{ Male } & $\begin{array}{c}\text { IX } \\
\text { class }\end{array}$ & Missionary & 3.39 & 0.81 & 25 \\
\hline & & Government & 3.59 & 0.78 & 25 \\
\hline & & Private & 3.21 & 0.73 & 25 \\
\hline & & Total & 3.40 & 0.78 & 75 \\
\hline & $\begin{array}{c}\text { XI } \\
\text { class }\end{array}$ & Missionary & 3.34 & 0.87 & 25 \\
\hline & & Government & 3.54 & 0.70 & 25 \\
\hline & & Private & 3.63 & 0.74 & 25 \\
\hline & & Total & 3.50 & 0.77 & 75 \\
\hline & Total & Missionary & 3.36 & 0.83 & 50 \\
\hline & & Government & 3.57 & 0.74 & 50 \\
\hline & & Private & 3.42 & 0.76 & 50 \\
\hline & & Total & 3.45 & 0.78 & 150 \\
\hline \multirow[t]{6}{*}{ Female } & $\begin{array}{c}\text { IX } \\
\text { class }\end{array}$ & Missionary & 3.68 & 0.58 & 25 \\
\hline & & Government & 3.87 & 0.91 & 25 \\
\hline & & Private & 3.62 & 0.99 & 25 \\
\hline & & Total & 3.72 & 0.84 & 75 \\
\hline & $\begin{array}{c}\text { XI } \\
\text { class }\end{array}$ & Missionary & 3.09 & 0.96 & 25 \\
\hline & & Government & 3.50 & 0.84 & 25 \\
\hline
\end{tabular}


An empirical study on socialization counseling needs of adolescents in Indian schools

\begin{tabular}{|c|c|c|c|c|c|}
\hline & & Private & 3.62 & 0.75 & 25 \\
\hline & & Total & 3.40 & 0.88 & 75 \\
\hline & Total & Missionary & 3.38 & 0.84 & 50 \\
\hline & & Government & 3.69 & 0.89 & 50 \\
\hline & & Private & 3.62 & 0.87 & 50 \\
\hline & & Total & 3.56 & 0.87 & 150 \\
\hline \multirow[t]{12}{*}{ Total } & $\begin{array}{c}\text { IX } \\
\text { class }\end{array}$ & Missionary & 3.53 & 0.72 & 50 \\
\hline & & Government & 3.73 & 0.85 & 50 \\
\hline & & Private & 3.41 & 0.89 & 50 \\
\hline & & Total & 3.56 & 0.83 & 150 \\
\hline & $\begin{array}{c}\text { XI } \\
\text { class }\end{array}$ & Missionary & 3.21 & 0.92 & 50 \\
\hline & & Government & 3.52 & 0.77 & 50 \\
\hline & & Private & 3.63 & 0.74 & 50 \\
\hline & & Total & 3.45 & 0.82 & 150 \\
\hline & Total & Missionary & 3.37 & 0.83 & 100 \\
\hline & & Government & 3.63 & 0.81 & 100 \\
\hline & & Private & 3.52 & 0.82 & 100 \\
\hline & & Total & 3.51 & 0.83 & 300 \\
\hline
\end{tabular}


Fig.1. Differences in schools in need for developing social relations

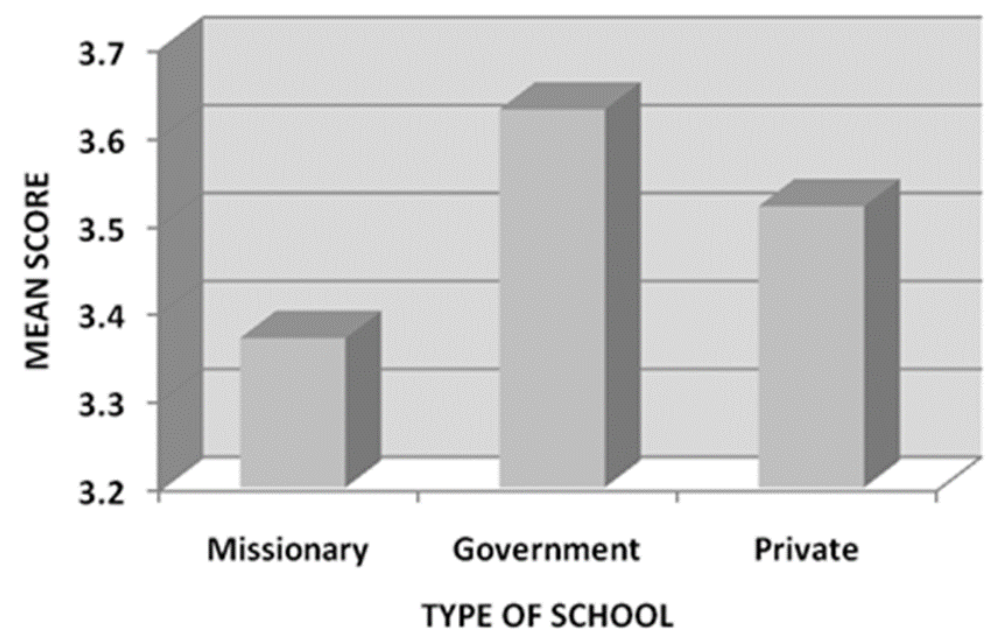

The results from Table. 2 reveal that the main effect of gender is not significant, $F(1,288)=$ $1.45, \mathrm{P}>0.05$. The effect of school on need for socialization counseling in the area developing social relations is found marginally significant $\mathrm{F}(2,288)=2.44, \mathrm{P}<0.10)$. Pattern of result also indicates that students studying in government school $(\mathrm{M}=3.37)$ displayed higher need of counseling in the area of developing social relations as compared to students belonging to private $(\mathrm{M}=3.11)$ and missionary $(\mathrm{M}=2.85)$ schools respectively. Results are also graphically represented in Fig. 1.

Table.3. Summary of ANOVA on need for developing social relations

\begin{tabular}{|c|c|c|c|c|}
\hline Source of Variance & $\begin{array}{l}\text { Sum of } \\
\text { squares }\end{array}$ & df & Mean Square & $\mathrm{F}$ \\
\hline Gender & 0.96 & 1 & 0.96 & 1.45 \\
\hline Class & 0.85 & 1 & 0.85 & 1.29 \\
\hline School & 3.24 & 2 & 1.62 & 2.44 \\
\hline Gender $*$ Class & 3.48 & 1 & 3.48 & $5.26^{*}$ \\
\hline Gender * School & 0.41 & 2 & 0.20 & 0.31 \\
\hline Class $*$ School & 3.98 & 2 & 1.99 & $3.01 *$ \\
\hline $\begin{array}{c}\text { Gender* Class * } \\
\text { School }\end{array}$ & 0.16 & 2 & 0.08 & 0.12 \\
\hline Error & 190.79 & 288.00 & 0.66 & \\
\hline
\end{tabular}


Fig.2. Two way interaction for gender and class for the need of developing social relations

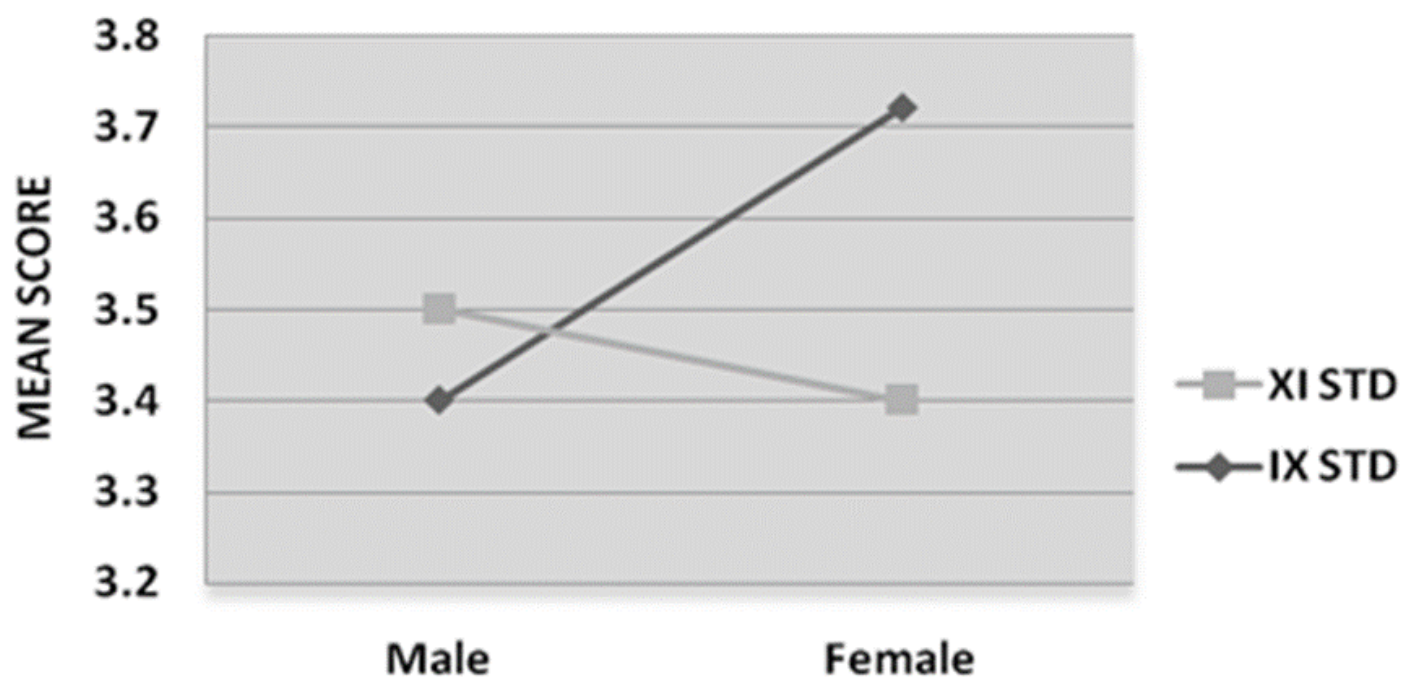

From Table. 3 results reveals that the main effect of school on need for developing social relations is found to be marginally significant $(\mathrm{F} 2,288)=2.444, \mathrm{P}<0.10)$, and results also reveals that main effect of gender is not significant, $\mathrm{F}(1,288)=1.45, \mathrm{P}>0.05$; Fig.2.)

Fig.3. Two way interaction of grade and school for need developing social relations

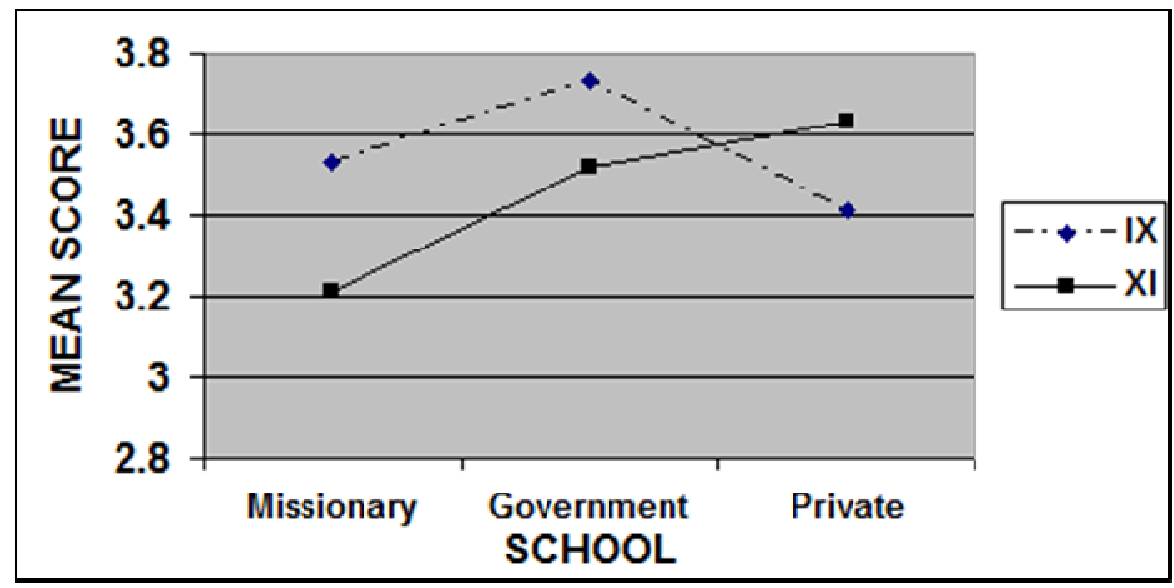

The result of interaction effect of gender with class is significant $\mathrm{F}(1,288)=5.26, \mathrm{P}<0.05$ (Table.3.). Male students studying in XI class $(M=3.50)$ showed greater need for developing social relations in comparison to IX class students $(\mathrm{M}=3.40)$; whereas, the female students studying in IX class $(\mathrm{M}=3.72)$ showed greater need for developing social relations in comparison to students $(M=3.40)$ studying in XI class (Fig. 2). A significant interaction effect of class with school for developing social relations $\mathrm{F}(2,288)=3.01, \mathrm{P}<0.05$ is also observed. Patterns of result reveals that IX class students from missionary school $(\mathrm{M}=3.53)$ and government school $(\mathrm{M}=3.73)$ experienced greater need for developing social relations than XI 
class students of missionary school $(\mathrm{M}=3.21)$ and government school $(\mathrm{M}=3.52)$. However, in case of private school, IX class students $(\mathrm{M}=3.41)$ experience lesser need for developing social relations as compared to XI grade students $(\mathrm{M}=3.63$; Fig. 3). Other results of interaction effects of gender with school and gender with class and school are not significant $\mathrm{F}(2,288)=0.31, \mathrm{P}<$ 0.05 and $\mathrm{F}(2,288)=0.12, \mathrm{P}<0.05$ respectively.

\section{Socio-economic status (SES)}

The effect of SES on the dimensions of socialization counseling needs are also investigated and the means and standard deviations of the scores indicating extent of counseling needs in relation to SES and summary of ANOVA is given in Table .4.

Table.4. Means and standard deviations of the scores and summary of one way ANOVA for counseling needs in relation to SES.

\begin{tabular}{|c|c|c|c|c|}
\hline $\begin{array}{c}\text { Source of } \\
\text { variance }\end{array}$ & & $\mathrm{N}$ & Mean & $\begin{array}{c}\text { Std. } \\
\text { Deviation }\end{array}$ \\
\hline $\begin{array}{c}\text { Developing Social } \\
\text { Relations (DSR) }\end{array}$ & 1.00 & 157 & 3.4193 & 0.8203 \\
\cline { 2 - 5 } & 2.00 & 143 & 3.6026 & 0.8239 \\
\cline { 2 - 5 } & Total & 300 & 3.5067 & 0.8257 \\
\hline \multirow{2}{*}{$\begin{array}{c}\text { Between groups } \\
\text { (DSR) }\end{array}$} & MS & $\mathrm{F}$ & & \\
\hline Within groups (DSR) & \multicolumn{2}{|c|}{0.67} & 3.71 & \\
\hline Total & \multicolumn{2}{|c|}{299} & & \\
\hline
\end{tabular}

$* * \mathbf{P}<0.01$, $* \mathbf{P}<0.05$

DSR:

Developing social

relations 
Fig.4. Effect of SES on the need for developing social relations socioeconomic status group

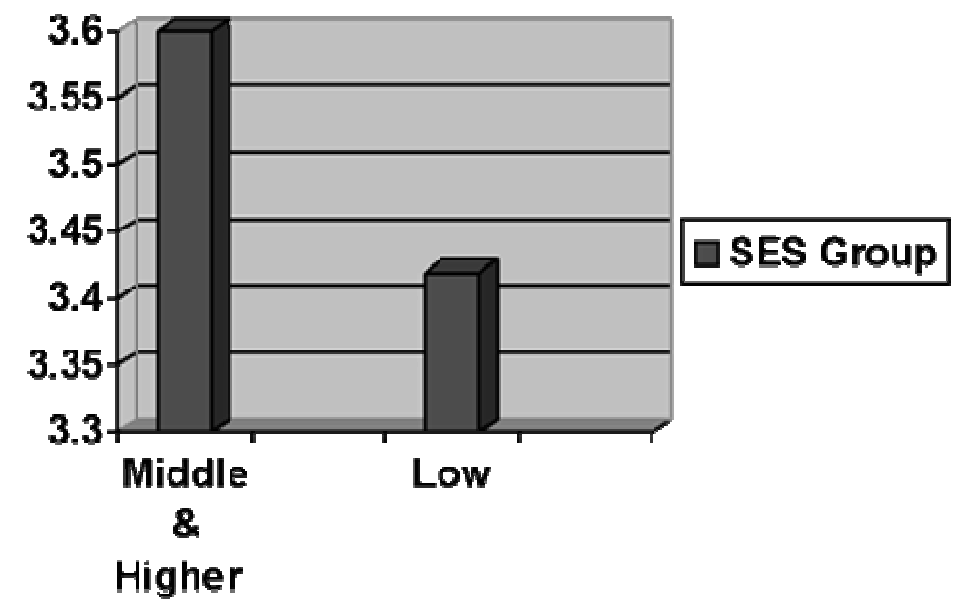

The result from Table. 4 is a close view on mean score patterns which reveals that adolescent students belonging to middle and higher SES group felt higher need for counselling in the area of socialization $(\mathrm{M}=3.60)$ as compared to low SES group $(\mathrm{M}=3.41)$. Summary of ANOVA supports that effect of SES on the socialization counseling need is significant $F(1,299)=3.71, P<0.05$. Hence, the result indicate that adolescents belonging to middle and higher SES show greater concern for socialization counselling (Fig. 4).

\section{DISCUSSION}

Adolescence is difficult for most youngsters, as it is a period during which an individual challenges self and childhood ideas (Jaffe, 1998). Adolescence is a turbulent time (Hoyer, 1998). At such times psychological counseling is a possible intervention. Adolescents have a tendency to view world with rose-tinted glasses (Russian, 1975). The main issues relating to adolescents are about understanding self, confronting family relationships, peer pressure and substance use/abuse issues; issues associated with psychological and emotional stress; sexual maturation issues, and school/academic issues (Pledge, 2003). Counseling is an interactive process that leads to a change in behavior, beliefs, values and level of emotional distress (Elizabeth \& Patterson, 2005). The study has its focus on knowing the socialization issues and needs of the adolescents that may require counseling. Socialization counseling is vital for psychosocial development and wellbeing of adolescents. Research supports this reflection concerning how socialization has consequences in a child's development as well as the psychosocial well-being (Hughes et al., 2006).

Our study shows that the government school indicated greater need for counseling in the area of socialization as compared to the private and missionary schools. This is because in government schools individual attention is almost rare and students most often have to look after themselves. Students of government school are the ones who get little attention and help from authorities. So these students show interest in being benefitted from counseling. The higher need from 
government school for counseling was because the learning environment is much more challenging with fewer resources as well as individualized attention of teachers. Schools can be a source of great help to adolescents, as research supports that school counselors are effective in teaching social skills (Verduyn \& Forrest, 1990).

The effect of gender did not produce significant effect on the need for counseling in the area of socialization. The result indicated that girls of IX standard and boys of XI standard showed greater need for developing social relations and hence showed inclination for counseling. An earlier report also suggested that late maturing boys are more psychologically restless than late maturing girls (Weatherley, 1964) and early maturing girls feel out of step with their peer group (Jones and Mussen, 1958).

\section{Socio-economic status and counseling need}

To ensure we know the pulse of the society, different levels of socio-economic population from different category of schools are targeted. The problems of adolescents are multi- dimensional in nature and require holistic approach. (Ali, 2014). The results indicate that the adolescents belonging to the middle and higher SES group showed greater need for counseling in the area of socialization and thus the need for counseling to develop social relations owing to less satisfaction with the present achievements. They further showed interest in improving and benefiting from counseling. According to reports of Bogie (1976) and Chaves et al. (2004), an aspiration expectancy discrepancy has been observed among lower SES adolescents but not among the higher SES. Counseling can help in lessening the gap between aspiration and expectation to some extent to some extent, which otherwise might go unattended. School counseling and guidance must be viewed as novel and critical educational factor in enhancing student development. It is suggested in this context that professional school counseling should be made mandatory for building welfare India emphasizing on the socialization area. There is a possibility to strengthen the secondary and the higher secondary stage of education by providing greater access and by improving quality of education through counseling of adolescents.

\section{CONCLUSION}

As investment in education has a direct bearing on the development of a country, a comprehensive help system must be promoted for adolescent well-being in schools. The report of the Working Group on Youth and Adolescents Development for $12^{\text {th }}$ Five Year Plan (2012-2017) essentially suggests that counseling centers should be established in all educational centers and so does this study. Teachers alone may not provide this kind of social support and hence professional socialization counseling must be necessary intervention for adolescents' optimal development. Counseling assists adolescents to be prepared for life as well as to cope with exigencies in future. 
An empirical study on socialization counseling needs of adolescents in Indian schools

\section{REFERENCES}

1. Ali, Shaik. (2014). Adolescence at Risk: Overview. The International Journal of Indian Psychology: 1:2348-5396.

2. Bogie, D.W. (1976). Occupational Aspiration-Expection Discrepancies among High school seniors. The Vocational Guidance Quarterly, 24: 250-255.

3. Boysen, G. A. \& Vogel, D. L. (2008). The Relationship between level of Training, implicit bias, and Multicultural competency among Counselor trainees. Training and Education in Professional Psychology, 2: 103-110.

4. Burger, J. M. (1997). Personality. Pacific Grove, CA: Brooks/Cole Pu.

5. Chaves, A.P, Diemer, M.A, Blustein, D.L, Gallagher, L.A, DeVoy, J.E, Casares, M.T. \& Perry, J.C. (2004). Conceptions of work: The View from Urban Youth. Journal of Counseling Psychologist, 51: 275-286.

6. Dubey, L.N \& Nigam, B. (2005). Scale of Socio Economic Status Urban. Psychological tests and apparatus. (Urban, 2005).

7. Dunbar, Edward. (2001) Counseling Practices to Ameliorate the Effects of Discrimination and hate events-toward a Systematic Approach to Assessment and Intervention. The Counseling Psychologist. 29: 281-310.

8. Edelbrock, C.S. (1989). Self-reported Internalizing and Externalizing problems in a community sample of Adolescents. Paper presented at the meeting of The Society for Research in Child Development, Kansas City.

9. Elizabeth, R. Welfel, \& Patterson, Lewis, E. (2005). The Counseling Process, Indian Reprint, New Delhi: Thomson.

10. Erikson, E. H. (1963a). Childhood and Society (2nd ed.) New York, Norton.

11. Erikson, E.H. (1963b). Reality and Actuality - an address. Journal of American Psychological Association, 10: 451-474.

12. Garbarino, J. (1995). Raising Children in a Socially Toxic Environment. San Francisco: Jossey-Bass Publishers.

13. Hoyer, P.J. (1998). Parental and parenting programs for adolescent mothers. Annual review of Nursing Research.16: 221-249.

14. Hoyt, S.L. (2011) Positive teens become Healthier Adults: Adolescents with a Sunny Outlook on Life may have Better Health in their Adult years, Journal of Adolescent Health, Northwestern University.

15. Hughes, D., Bachman, M. Ruble, D., \& Fuligni, A. (2006). Tuned in or tuned out: Children's interpretations of parents' racial socialization messages. In L. Balter \& C. Tamis-Lemonda (Eds.), Child Psychology: A Handbook of Contemporary Issues (2nd ed., pp. 591-610). Philadelphia: Psychology Press.

16. Inhelder, I., and Piaget, J. (1958). The Growth of Logical Thinking. New York: basic books.

17. Jaffe, M. L. (1998). Adolescence. New York: John Wiley \& Sons. 
18. Jones, M.C, \& Mussen, P. H. (1958). Self-conceptions, Motivations and Interpersonal attitudes of early and late maturing girls, Child Development, 29: 491-501.

19. Kohlberg, L. (1969), "Stage and Sequence," Handbook of Socialization Theory and Research, Mcgraw hill: New York.

20. Lee. M, Richard. (2003). The Transracial Adoption Paradox-history, Research, and Counseling Implications of Cultural Socialization. The Counseling Psychologist, 31: 711744.

21. Linda, Darling-Hammond, (1997). The Right to Learn: a Blueprint for Creating Schools that Work, Jossey-Bass Education Series, Illustrated, 1-27.

22. Muss, R. E. (1990). Adolescent Behavior and Society. New York: Harper and Row. A Book of Readings (4th ed.)

23. Pledge, Deanna, S. (2003). When Something Feels Wrong: A Survival Guide About Abuse for Young People. Minneapolis, MN: Free Spirit.

24. Reber, S. Arthur. (1995). Dictionary of Psychology. Penguin Publications, Second Edition.

25. Tatum, B. D. (1987). Assimilation blues: Black families in a White community. Westport, CT: Greenwood Press.

26. Urciuoli, B. (1996). Exposing Prejudice: Puerto Rican experiences of Language, Race, and Class. Boulder, CO: Westview Press.

27. Verduyn, C.M., Lord, W.\& Forrest, G.C.(1990).Social Skills Training in Schools: An evaluation study. Journal of Adolescence, 13: 3-16.

28. Ward, J. (1991). Eyes in the Back of your Head: Moral themes in African American narratives of Racial Conflict. Journal of Moral Education, 20, 22: 267-281.

29. Weatherly, D. (1964). Self-perceived rate of Physical Maturation and personality in late adolescence. Child Development, 35: 1197-1210.

30. Zill, N., Collins, M., West, J. \& Hausken, E.G. (1995). School Readiness and Children's Development Status. ERIC Digest. 